\title{
Rising sea level and long term sustainability of near-shore islands of the United Arab Emirates: an approach to establishing setback lines for Abu Dhabi
}

\author{
G. G. Garland \\ Geography and Urban Planning, University of United Arab Emirates, \\ Al Ain, UAE
}

\begin{abstract}
In recent years an important infrastructural and human development focus for the United Arab Emirates has been along the shoreline of its northern coast fronting the Arabian Gulf. The Gulf itself is a large, warm, shallow semi-enclosed body of water with complex oceanography and geomorphological history. Its southern shores, including that of the northern UAE, are predominantly sandy. The value of present infrastructure, especially in the capital city Abu Dhabi, constructed on a number of natural and man-made islands, is enormous, but is already dwarfed by future plans for the next twenty years. It is obvious that for the plans to be both implementable and sustainable, the impacts of future sea level changes must be taken into account.

Restricting sea level impact analysis to plotting the slow creep of steadily rising sea level up the shore over several decades is naive and ignores other significant changes in flood risks that accompany rising sea level. These include enhanced coastal erosion, higher extreme tides and waves, elevated low pressure surges and greater wave runup, all of which increase the likelihood of flood occurrence and the degree and intensity of damage.

This paper reviews past and future sea level changes in the Arabian Gulf, and demonstrates that, notwithstanding its separation from world oceans, the Gulf sea level tends to respond to global forcing in the same way and within approximately the same time frames as the global oceanic system. The study concludes that from present evidence, the most likely sea level rise scenarios for the Gulf by 2099 lie between 0.21 and $2 \mathrm{~m}$. Then, after review of many of the
\end{abstract}


relevant variables, it proposes an 8-step procedure for developing safe development setback lines for the islands and shoreline of Abu Dhabi city. The approach should be applicable for the islands and shorelines anywhere in the southern Gulf.

Keywords: Arabian Gulf islands, Abu Dhabi, sea level rise, tide and storm surges, Shamal wind, setback lines.

\section{Introduction}

It is now well established that global sea level will increase significantly over the next few centuries, irrespective of whether greenhouse gas emissions can be reduced or not. This will have notable effects on small islands around the world, since for various reasons many are exceptionally vulnerable [1]. In general the Arabian Gulf region is not well researched with respect to past or future sea level changes, although Desgupta et al. [2] demonstrated that in the Middle East and North Africa, the UAE would be one of the most impacted countries, together with Egypt and Qatar.

The UAE abuts the southern Arabian Gulf (Fig 1) and has sovereignty over almost 200 small Gulf Islands, and an increasing number of near-shore manmade structures such as Lulu Island, just seaward of Abu Dhabi Island. Many of the natural islands are or have been inhabited for hundreds of years and are

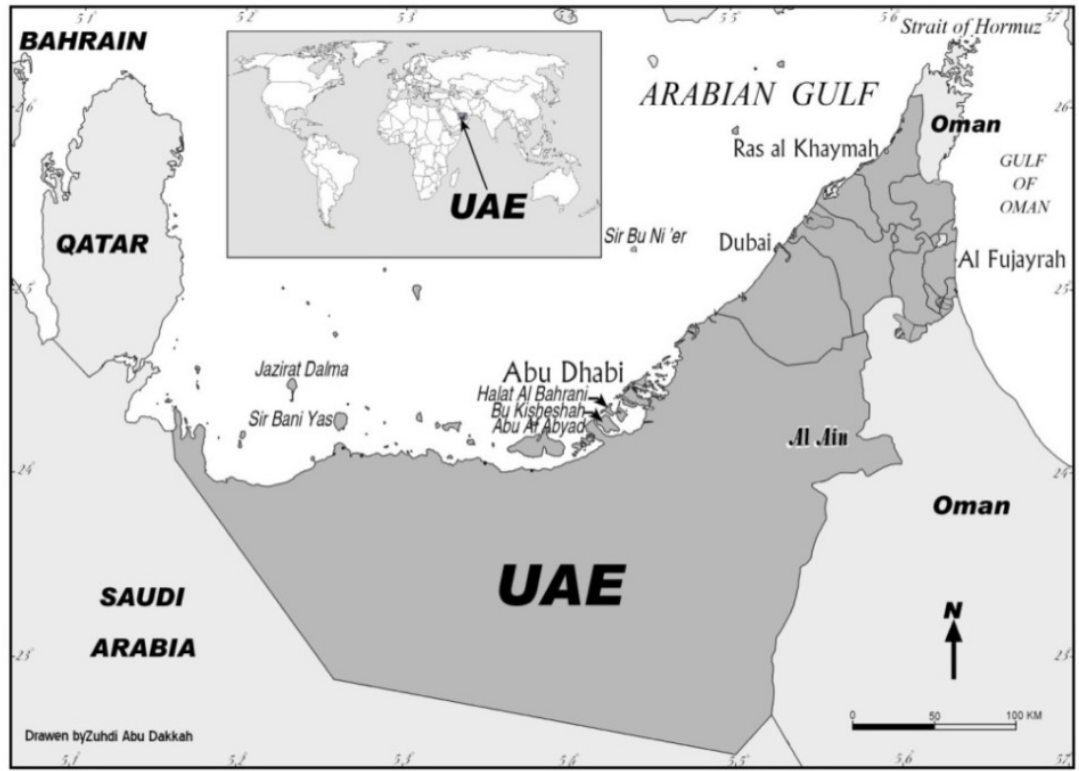

Figure 1: The UAE, Abu Dhabi and some of the main Gulf islands. 
becoming important destinations for cultural tourism. Most of the artificial structures as well as some natural islands have maximum elevations only a few metres above sea level.

The city of Abu Dhabi (Fig 1), itself located on a low lying natural island, is by far the most developed of the all the Emirates islands, and boasts an impressive and growing infrastructure. Its future plans are spectacular and costly, construction on a number of elements has already begun, and one, the Formula One circuit on Ras Island is already complete. Abu Dhabi island itself is linked to the mainland by three bridges. It has an area of $95 \mathrm{~km}^{2}$, with a maximum elevation some $20 \mathrm{~m}$ above present sea level. Its vulnerability to changing sea level and associated marine impacts is thus-far not clear.

The physical impacts of sea level change on all shorelines, including those of islands, is not limited to gradual inundation as sea encroaches on low lying land. A second probable result is enhanced shoreline erosion [3]. A third is increased coastal flooding during unusual tidal and meteorological events, especially if these occur together [4]. For construction and development purposes these should ultimately be used to establish safe setback lines based on permanent inundation, extreme tides and weather conditions, and vulnerability to coastal erosion, such that risk of damage to infrastructure and human life is minimised landward of the line. Seaward areas of setback lines present additional risk, and building and construction will require more protection.

The objectives of this paper are formulated with the Abu Dhabi city island in mind, although results should be valid for most Gulf islands. Thus the paper will:

- Determine the most likely sea level rise scenarios for the Abu Dhabi city shoreline for the year 2100

- Review and assess the likelihood and magnitude of storm surges, high significant waves and extreme tides occurring in this part of the southern Gulf

- Outline the research requirements for coastal erosion predictions for new shoreline positions

Lack of measured data for the southern Gulf in most physical marine disciplines, means that methods are based on review, analysis and final synthesis of existing information. The precise calculation of maximum impact lines for selected sea level scenarios - remains the topic of future work, although an eightstep procedure and requirements for necessary prior research are developed.

The best possible sea level rise scenarios, as well as maximum storm surge, highest significant wave, and Highest Astronomical Tide will all be obtained from existing data. Mapping of coastal landforms to assess vulnerability to erosion is a research project on its own and will not be undertaken here. 


\section{Variables controlling sea level change and its impacts at Abu Dhabi}

\subsection{Sea level change in the southern Arabian Gulf}

\subsubsection{Historic and present sea level changes}

No data or reports were found that deal specifically with Abu Dhabi and its islands, although there are assessments for the Arabian Gulf. Given the confined and coherent nature of the Gulf, it is reasonable to assume that they have at least some validity for Abu Dhabi. However the data suffer from very short measurement runs, and restricted spatial extent.

Work on Holocene shorelines at Umm Al Quwayn Lagoon by Bernier et al. [5] makes it clear that since it was filled approximately 11500 years ago, Gulf sea level has fluctuated significantly in the last 10000 years, and will probably continue to do so. They found geomorphological and archaeological evidence of sea level higher than at present 6000, 4500, 3500, 2600 and 1470 years ago, each separated by regression. Similar fluctuations have been observed at Bahrain [6], and Failak Island (Kuwait) [7]. Although these changes pre-date any sea level change precipitated by anthropogenic global warming, they broadly agree with eustatic changes over the same periods, and show that notwithstanding its separation from world oceans, Gulf sea level tends to respond in the same way and within the same time frames as the global ocean system to eustatic changes. This means that eustatic predictions must have some validity for the Arabian Gulf.

Recent sea level change is difficult to establish due to a number of factors, the most important being paucity of long runs of local measured data. To be truly valid, continuous tidal gauge measurements of at least 50 years are necessary to determine trends of sea level, and nowhere does such data exist for the Gulf. Further, Sultan et al. [8] demonstrate that large seasonal temperature, pressure and water density fluctuations, together with high evaporation rates and significant fresh water inflow lead to a notable seasonal sea level fluctuation, whereby summer levels are up to $260 \mathrm{~mm}$ higher than in winter. This is far greater that any possible annual change. Nevertheless the same authors, using an 11 year data set from two Saudi Arabian (south western Gulf) stations were able to identify a positive sea level trend of some $2.1 \mathrm{~mm}$ per year. Later Hosseinibalam et al. [9], using 10 years (1999-2000) of data from northern Gulf stations came to similar annual and seasonal conclusions, proposing a sea level rise of for the northern Gulf of $2.34 \mathrm{~mm}$ per year.

\subsubsection{Future sea level rise}

The IPCC [10] point out that

"Anthropogenic warming and sea level rise would continue for centuries due to the time scales associated with climate processes and feedbacks, even if greenhouse gas concentrations were to be stabilized" (p26)

There is little doubt that future increase of sea level in the Gulf is predicated, the question is how much? In the absence of local data specific to the southern 
Gulf, and with the assumption that sea level in the Gulf mirrors global oceanic sea level behaviour, best future sea level predictions (Table 1) are adopted directly from Sultan et al. [8], IPCC [10], Rhamsdorf et al. [12] and Pfeffer et al. [13].

Sultan et al.'s [8] measurements are for an 11 year period only and are now 14 years out of date. They do not take account of any future global warming effects, and, if computed through to 2099 they may be considered as the minimum likely sea level change. The IPCC report predicts a minimum global increase of $0.18 \mathrm{~m}$, and a maximum of $0.59 \mathrm{~m}$ by 2099 . These values are contested by Rahmsdorf et al. [12], who make a strong case to suggest that they are an underestimate, and eustatic rise could be as much as $0.81 \mathrm{~m}$ by 2099 . However, since there is still much uncertainty over global warming, errors could cause additional infrastructure damage and even loss of life. It therefore makes sense to invoke the precautionary principle. Thus, based on best current understanding of the present global warming cycle and all other influential factors, the highest possible rise - a value which cannot be exceeded by 2099 is, according to Pfeffer et al. [13], 2m. They base their conclusion on an analysis of the kinematics of ice melt and oceanic heat distribution. Taking all these estimates into account, Table 1 proposes low, medium, high and extreme scenarios for the shorelines of Abu Dhabi City and its associated islands for the year 2099.

Table 1: $\quad$ Most probable sea level rise scenarios for Abu Dhabi for the year 2099.

\begin{tabular}{|c|c|c|c|c|c|c|c|}
\hline \multicolumn{2}{|c|}{$\begin{array}{c}\text { Low Scenario } \\
\text { (Sultan et al. [8]) }\end{array}$} & \multicolumn{2}{c|}{$\begin{array}{c}\text { Medium } \\
\text { Scenario } \\
\text { (IPCC [10]) }\end{array}$} & \multicolumn{2}{|c|}{$\begin{array}{c}\text { High Scenario } \\
\text { (Rhamsdorf et al. } \\
[12])\end{array}$} & $\begin{array}{c}\text { Extreme Scenario } \\
\text { (Pfeffer et al. } \\
[13])\end{array}$ \\
\hline 1 & 2 & 1 & 2 & 1 & 2 & 1 & 2 \\
\hline$+\mathbf{2 . 1} \mathbf{m m}$ & $+\mathbf{0 . 2 1} \mathbf{m}$ & $\mathbf{+ 6 . 6 m m}$ & $\mathbf{+ 0 . 5 9 m}$ & $\mathbf{+ 9 . 0 m m}$ & $\mathbf{+ 0 . 8 1 m}$ & $\mathbf{+ 2 0 . 2} \mathbf{m m}$ & $\mathbf{+ 2 . 0 m}$ \\
\hline
\end{tabular}

$1 \mathrm{mean}$ annual rise in $\mathrm{mm}$; 2 total increase in sea level by 2099 in $\mathrm{m}$.

\subsubsection{Gulf sea surface elevations due to tides and storms.}

Lack of appropriate measured data, means that modelling based on expected tide, wind and storm information has been used in most existing analyses of southern Gulf conditions. Most models also integrate both tide and storm surges to produce a single value, an approach used to good effect for Dubai by Mangor et al. [14]. Tides are predictable, and Highest Astronomical Tides tend to occur every 18 years or so, and can be up to $20 \mathrm{~cm}$ above normal spring highs.

Arabian Gulf climate is dominated by extra-tropical weather systems which in the main travel from north west to south east [15]. By far the most dominant and intense of these is the Shamal storm system which moves offshore from Iraq and Kuwait into Gulf waters and, although it can occur in summer, is most common and powerful between the months of November and March. Because of its nature, its effect on sea surface elevation is two-fold. First, It creates an extensive, and largely uni-directional wind field which tends to force Gulf 
surface waters towards the south and east, causing a significant build up in the south eastern regions of the Gulf. Second, atmospheric pressure differentials can create both negative and positive surges [16].

The consequences to storm sea levels from the former are best demonstrated by Delft Hydraulics [17]. They noted that variations in Gulf surface level elevation are most strongly determined by a complex tidal regime, with wind and water density also playing significant roles. Using the Delft3D-FLOW model, calibrated with readings form 130 coastal and offshore stations, they demonstrated that extreme Shamal events, such as that in 1964, resulted in an increase in sea surface elevation off Abu Dhabi of about $1 \mathrm{~m}$. Whether this figure includes an element due to pressure variation is unclear.

However, surges due to atmospheric pressure variation were investigated by $\mathrm{El}$ Sabh and Murty [15]. Absence of measured data resulted in the use of a modelling approach from which they concluded that positive surges - most important for flood assessment potential - for a long duration Shamal with winds blowing consistently from the north west can result in a positive surge of up to $4 \mathrm{~m}$ at Jazirat Ghagha, a near-shore recording station some $200 \mathrm{~km}$ west of Abu Dhabi city.

In conclusion, there is clearly conflict between modelling results. Using the precautionary principle, information currently available suggests that a maximum sea surface elevation along the Abu Dhabi shoreline due to both driving wind and atmospheric pressure differentials is about $4 \mathrm{~m}$. The return period of such an event is unknown but could certainly happen a number of times by 2099. Unless more precise data becomes available, this should be used in the calculation of impact lines for Abu Dhabi.

\subsubsection{Highest significant waves}

Like most oceanographic variables needed for analysis in the Arabian Gulf, assessment of wave climate suffers from lack of long runs of reliable measured data. This has led to modelling of wave height, period and length based on the transfer of wind energy to the water surface.

It is unfortunate that two of the most accepted analyses for the region using this approach give contradictory results. Delft hydraulics [17] used the wavefocussed SWAN module of the Delft3D-Flow model to predict wave fields and significant wave heights for the whole of the Gulf during an extreme Shamal event, with wind direction predominantly from the northwest, and including a sub-set from the north. The results showed the Abu Dhabi coastline to be largely sheltered from its effects by the Qatar peninsula, such that significant wave heights rarely exceeded $1 \mathrm{~m}$.

In contrast, Neelamani et al. [18], employed a WAM model using data from 39 widely distributed stations in the Arabian Gulf to hindcast significant wave heights and probabilities based on a Weibull distribution, for 12 years between 1993 and 2004. They found that for their station 14, only a few km from Abu Dhabi, significant wave height varied from $4 \mathrm{~m}$ with a 12 Year return period to $5 \mathrm{~m}$ for a 100 year return.

The differences between the two modelling results are significant, and if anything points to the conclusion that modelling may be a poor substitute for 
measured data. Nevertheless, since for this study it wise to employ the precautionary principle, it is prudent to employ the highest modelling estimate available for assessment of maximum impact lines for 2099 for the Abu Dhabi islands. Here we may note that Neelamini et al's higher results [18] find support from a detailed assessment of wave and tide characteristics for Dubai, some 120 $\mathrm{km}$ to the north east [14]. In a study to assess the effects of offshore developments on the present coastline, they employed the PERGOS model to hindcast highest significant waves for the same 12 year period. They caution that the results are best estimates only, but concluded that the 50 year highest significant wave height in the Dubai area is between $3-4 \mathrm{~m}$. On this basis it is reasonable to assume that a $5 \mathrm{~m}$ significant wave height will occur at least once along the Abu Dhabi shoreline before 2099, with approximately 8 occurrences of $4 \mathrm{~m}$ waves during the same period.

\subsubsection{Vulnerability to shoreline retreat}

Predicting the likelihood and amount of shoreline retreat on sandy coasts without barriers under increasing sea levels is a complex and controversial business. Since the 1950's the Bruun Rule [19-21] has been used to estimate retreat on hundreds of shorelines around the world. It is a 2-dimensional model which proposes that on otherwise stable beaches unaffected by longshore drift or other influences, then the amount of shoreline retreat is directly proportional to rise in sea level:

$$
R=-S \frac{w}{h+B}
$$

Where $R$ is shoreline retreat; $S$ is rise in sea level; $w$ is width of the shoreface; $h$ is water depth of the shore face; and $B$ is the height above water level of the exposed beach.

Under such a scenario shoreline retreat can be as much as 100 times the increase in sea level, and although a few researchers, for example Rosen [22] have found the model to be effective, it is strongly contested by many, most notably by Cooper and Pilkey [23], but also by others. They contend that the assumptions demanded by Bruun's model are so stringent that they are rarely met on natural beaches, and out of the hundreds of times the rule has been used around the world, there are few applications which support it. Amongst its problems are that it fails to take account of on-or off-shore sediment sources, longshore drift and variations in wave climate and energy. Bird [24] suggests that the model could only be correct after sea level has stabilised at a new equilibrium level.

Our present understanding of the shoreline geomorphology of the Abu Dhabi is poor. There have been few if any prior studies of recent coastal erosion or of the nature and effect of the near shore current system on sediment transport. Longshore drift at Dubai is in a north easterly direction [14], and Maddrell et al. [25] claim that Dubai's gross drift rate is in the order of some $100000 \mathrm{~m}^{3}$ per year. However given the differences in coastal and nearshore landforms between the two city shorelines this information may well not hold for Abu Dhabi. Howari and El-Saiy [26] studied characteristics of sediments between Abu Dhabi 
and Dubai. They concluded that supratidal sediments became finer towards Abu Dhabi, but that all sediments along the coastal reach between the two cities were of marine origin. The marine origin suggests that onshore sediment transport may be the dominant beach sediment source. The fining out towards Abu Dhabi may indicate that longshore drift mechanisms may be less powerful as one moves south eastward from Dubai.

However, without a thorough study of the nature of the coastal sediment transport regime of Abu Dhabi, and since the Bruun Rule may not be appropriate for particular coastal configuration, neither the location of sites vulnerable to erosion nor the expected rates of shoreline retreat for the city can be assessed at this time.

\section{Conclusions}

It is clear from the IPCC's warning [10], that irrespective of any global reductions in greenhouse gas emissions, sea level will continue to rise for at least a few centuries.

This being the case, and since Arabian Gulf sea levels as far as we know mirror world-wide eustatic changes, it is fair to conclude that sea level rise estimates for the year 2099 in Table 1 are the best assessments possible.

The additional affects of tides, low pressure surges and high significant waves is less clear. Modelling of these has, in the main produced equivocal results. Not only this, but the shoreline impact of waves in particular, and any enhanced potential for coastal erosion, depends on the degree of exposure to the open sea. In narrow channels such as those separating the islands of Abu Dhabi, or protected sites, such as Abu Dhabi Corniche, sheltered by Lulu Island, storm and tidal surges will have an effect, but wave impact could be reduced significantly. Conversely Marina Mall Island and Emirates Palace Beach will be subject to greater impact, with correspondingly greater dependence on engineered protection.

Thus at this stage, the best possible estimates for sea level rise impacts on the Abu Dhabi city islands must be general rather than site specific (Table 2). They

Table 2: Maximum sea heights above present datum accompanied by extreme tide, storm surge and wave events, by sea level rise scenario for the Abu Dhabi city area for 2099.

\begin{tabular}{|c|c|c|}
\hline $\begin{array}{c}\text { 1 SEA LEVEL RISE } \\
\text { SCENARIO }\end{array}$ & $\begin{array}{c}\text { 2 SHELTERED SITES } \\
\text { (including storm and tide } \\
\text { surges }(4 \mathrm{~m}), \text { but excluding } \\
\text { wave and erosion effects) }\end{array}$ & $\begin{array}{c}\text { 3 SITES EXPOSED } \\
\text { TO OPEN SEA } \\
\text { (including storm and } \\
\text { tide surges }(4 \mathrm{~m}), \text { and } \\
\text { expected highest } \\
\text { significant } \\
\text { waves }(4 \mathrm{~m}))\end{array}$ \\
\hline$+21 \mathrm{~cm}$ (Sultan et al. $[8])$ & $+4.21 \mathrm{~m}$ & $+8.21 \mathrm{~m}$ \\
\hline$+59 \mathrm{~cm}$ (IPCC $[10])$ & $+4.59 \mathrm{~m}$ & $+8.59 \mathrm{~m}$ \\
\hline$+81 \mathrm{~cm} \mathrm{(Rhamsdorf} \mathrm{[12])}$ & $+4.81 \mathrm{~m}$ & $+8.81 \mathrm{~m}$ \\
\hline$+2 \mathrm{~m} \mathrm{Pfeffer} \mathrm{et} \mathrm{al.}[13])$ & $+6.00 \mathrm{~m}$ & $+10.00 \mathrm{~m}$ \\
\hline
\end{tabular}


should be based on the precautionary principle, and exclude coastal erosion effects until better data become available.

Within these restrictions, Table 2 uses the sea level rise scenarios, together with the highest storm and tide surges, to assess the worst case scenarios of maximum water height above present datum that are likely to occur by 2099 . Note that in addition to the incremental increases in sea level, the values in columns 2 and 3 represent long return period events which may occur only a few times by 2099 .

\section{Recommendations}

In the absence of more precise data, future planning should proceed with the values from Table 2 in mind. In order to obtain more accurate data for calculation of setback lines for Abu Dhabi and associated islands, the flow diagram in Figure 2, which shows an eight-step procedure for calculating set back line location should be used as guideline

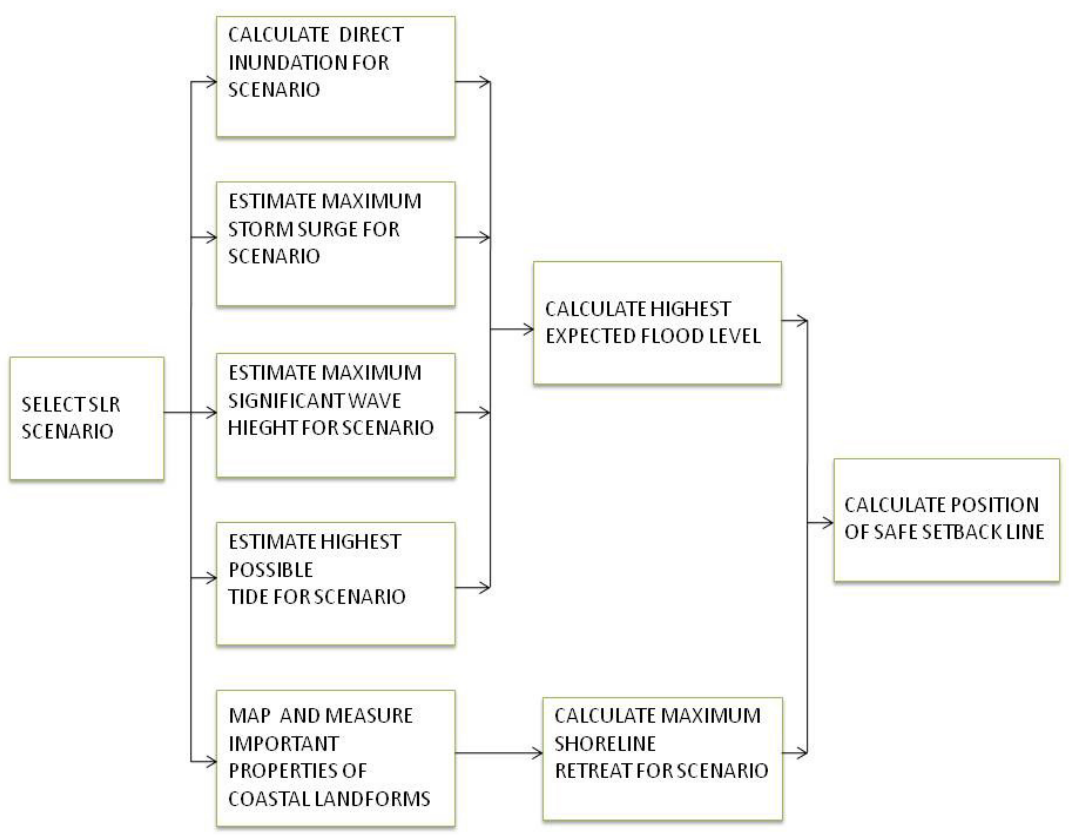

Figure 2: $\quad$ Procedure for establishing coastal set back line positions for infrastructural development and construction in the coastal zone.

To provide the basic data for this, a number of enabling steps need to be taken:

i. $\quad$ Establishment of a wave climate and sea-level monitoring system using a judiciously sited tidal and wave gauge network 
ii. A detailed survey of the current systems of the shoreline and channel system

iii. Mapping and assessment of the shoreline and channel landforms and processes

$i v$. A thorough and detailed assessment of past and present shoreline and channel erosion and sedimentation

v. Mapping and assessment of the variation in vulnerability to sea level impacts of the complete Abu Dhabi City shoreline and channel system

Although some of these, such as i) have medium to long term value only, all are essential to developing accurate impact lines for Abu Dhabi City.

\section{References}

[1] Mimura, N., L., Nurse, R.,F., McLean, J., Agard, L., Briguglio, P., Lefale, R., Payet, A., \& Sem, G. Small islands.(Chapter 16) Climate Change 2007: Impacts, Adaptation and Vulnerability. Contribution of Working Group II to the Fourth Assessment Report of the Intergovernmental Panel on Climate Change, eds, M.L. Parry, O.F. Canziani, J.P. Palutikof, P.J. van der Linden and C.E. Hanson, Cambridge University Press, Cambridge, UK, pp. 687-716, 2007.

[2] Dasgupta, S., Laplante, B., Meisner, C., Wheeler, D., \& Yan, J. The Impact of Sea Level Rise on Developing Countries: A Comparative Analysis. World Bank Policy Research Working Paper 4136, pp. 16-22, 2007.

[3] Masselink, G., \& Hughes, M. Introduction to Coastal Processes and Geomorphology Arnold, London, pp. 39-44, 2003.

[4] Mather, A., \& Vella, G. Report on the March 2007 coastal erosion event for the KwaZulu-Natal Minister of Agricultural and Environmental Affairs. Unpublished Report, eThekwini Municipality. Durban, South Africa, 9pp. 2007.

[5] Bernier, P., Dalongville, R., Dupuis, B., \& de Medwecki, V. Holocene shoreline variations in the Persian Gulf: an example of the Umm Al Qowayn Lagoon (UAE). Quaternary International, 29/30 pp. 95-103, 1995.

[6] Sanlaville, P., \& Paskoff, R. Shoreline changes in Bahrain since the beginning of Human occupation, Manema (Bahrain), eds, Shaika Haya Ali Al Khlaifa and M Rice, Bahrain Through the Ages Conference 3-9 Dec 1983 Proceedings, KPI Lid, Manama, Bahrain, London, pp. 15-24, 1996.

[7] Dalongville, R. Presentation physique generale de l'ile de Falaika (Koxeit). Eds, Y. Calvet Y \& J. Gachet, Falaika, Fouille Francaise 1986-1988, TMO no 18, Maison de Lorient, Lyon, pp. 23-40, 1990.

[8] Sultan. S., A., R., Ahmad, F., El Ghribi, N., M., \& Al Subhi, A., M. An analysis of Gulf monthly mean sea level, Continental Shelf Research 15, No 11/12, pp. 1471-1482, 1995.

[9] Hosseinibalam, F., Hassanzadeh, S., \& Kiasatpour. A. Interannual variability and seasonal contribution of thermal expansion to sea level in the Persian Gulf, Deep Sea Research Part 1: Oceanographic Research Papers 54 (9) pp. 1474-1485, 2007. 
[10] IPCC, Synthesis Report adopted by IPCC Plenary XXVII (Valencia, Spain, November 27-30, pp. 34-76, 2007.

[11] Nicholls, R.J., Wong, P. P., Burkett, V. R., Codignotto, J. O., Hay, J. E., McClean, R.F., Ragoonaden, S. \& Woodroffe C., D. Coastal systems in low-lying areas (Chapter 6). Climate Change 2007: Impacts, Adaptation and Vulnerability. Contribution to Working Group II to the Fourth Assessment Report of the Intergovernmental Panel on Climate Change, eds M. L. Parry, O.F Canzinai, J. P. Palutikof, P. J. Van der Linden \& C. E. Hanson. Cambridge University Press, UK, pp. 315-356, 2007.

[12] Rahmsdorf, S., Cazenave, A., Church, J., Hansen, J., Keeling, R., Larker, D. \& Somerville, R. Recent climate observations compared to future projections. Science 316, p709, 2007.

[13] Pfeffer, W., T., Harper, J., T., \& O’Neel, S. Kinematic constraints on Glacier contributions to $21^{\text {st }}$ century sea Level rise. Science 5, Vol 321, no 5894, pp. 1304-1343, 2008.

[14] Mangor, K., Mocke, G., Giarusso, C., Smit, F., Bloch, R., Fuchs, J., Lumborg, U. \& Neimann, S. Shoreline management of the Dubai coast. COPEDEC VII, Dubai 24-28 Feb, Paper M-15, pp 134-145, 2008.

[15] El Sabh, M., I., \& Murty, T., S. Storm surges in the Arabian Gulf. Natural Hazards 1, 371-385, 1989.

[16] Murty, T., S., \& El Sabh, M., I. Storm tracks, storm surges and sea state in the Arabian Gulf, Straits of Hormuz and Gulf of Oman, ed, M. I. El Sabh, Oceanographic modelling of the Kuwait Action Plan (KPA) region. UNESCO Reports in Marine Sciences No 28, pp. 12-22. 1984.

[17] Delft Hydraulics Hydrodynamic modelling of the Arabian Gulf. Delft Hydraulics, Delf, Netherlands, www.wldelft.nl. (Undated).

[18] Neelamani, S., Al-Salem, K., \& Rakha, K. Extreme waves in the Arabian Gulf. Journal of Coastal Research, SI 50 (Proceedings of the 9th International Coastal Symposium), 322 - 328. Gold Coast, Australia, 2007.

[19] Bruun. P. Coastal erosion and the development of beach profiles. US Army Beach Erosion Board, Technical Memorandum 44, pp 1037-1042, 1954.

[20] Bruun, P. Sea level rise as a cause of shore erosion. Journal of Waterway, Port Coastal and Ocean Engineering, ASCE 88, pp. 117-130, 1962.

[21] Bruun, P. The Bruun Rule of erosion. A discussion on large-scale two and three dimensional usage. Journal of Coastal Research 4, pp. 626-648, 1988.

[22] Rosen, P. A regional test of the Bruun Rule on shoreline erosion. Marine Geology 26, pp. M7-M16, 1977.

[23] Cooper, J., A., G \& Pilkey, O., H. Sea-level rise and shoreline retreat: time to abandon the Bruun Rule. Global and Planetary Change 43, pp. 157-171, 2004.

[24] Bird, E. Coastal Geomorphology-an Introduction. John Wiley and Sons, Chichester, pp.280-282. 2000.

[25] Maddrell, R., Burgess, K., \& Hamer, B. Short and long term impacts of the construction of coast defences on coastal erosion. Coasts \& Ports Australasian Conference, Auckland, 9-12 Sept, 2003. 
146 Island Sustainability

[26] Howari, F., M \& El-Saiy, A., K. Characterization of Recent Sediments between Abu Dhabi and Dubai Coasts, United Arab Emirates, with Multiple Analytical Techniques. Journal of Coastal Research 24 (2B) pp.74-82, 2008. 